\title{
The Impact of Microfinance Banks on the Growth of Small and Medium Enterprises in Lagos Metropolis
}

\author{
Olufemi Aladejebi ${ }^{1}$
}

\begin{abstract}
Small and Medium Enterprises (SMEs) play a major role in the Nigerian economy, especially in terms of Employment, growth, productivity, and poverty alleviation. The purpose of this study was to examine the impact of Microfinance Banks (MFB) on the growth of SMEs in Lagos metropolis The data for this study was collected via questionnaires given to the owners of SMEs that had accounts with microfinance banks in Lagos metropolis. Out of 209 questionnaires distributed, 205 were viable and analyzed using the SPSS package. The questionnaire contained 2 sections. Section 1 for general information while section 2 contains questions on effects of micro-savings on financial performance, effects of microcredit on the financial performance of the SMEs, effects of training on the financial performance of the SMEs and financial performance. The outcome revealed that the savings among SMEs are encouraging because of higher interest rates compared to deposit banks, faster loan disbursement, failure of MFBs to conduct training for SMEs, while the majority of SMEs experienced financial growth using MFB products.
\end{abstract}

Keywords: Small business, Microfinance banks, SME growth, Lagos metropolis

\section{Introduction}

Access to finance and credit plays a significant role in sustaining livelihoods and developing microenterprises. Inaccessibility of such credit continues to hinder this development. The formal financial institutions view these enterprises as risky and unprofitable and are, therefore, hesitant to provide such credit to them (Sanya, \& Polly, 2017). The fundamental role of MFBs is that of the provision of financial intermediation. This is the transfer of capital or liquidity from those who are in surplus to those in deficit (Ekpete \& Iwedi, 2017). MFBs play important roles in the economic growth and development of any government because of their potentials in poverty reduction (Adama, Duru, \& Diyoke, 2017). Globally, SMEs are known for their leading role in promoting grassroots economic and equitable sustainable development (Wairimu \& Mwilaria, 2017). According to Chetama, Dzanja, Gondwe \& Maliro, 2016, a vibrant micro, small, and medium enterprise (MSME) sector is key to poverty alleviation and growth in, especially in sub-Saharan Africa. Microfinance institutions and banks have been used as a tool to provide support and microcredit to small businesses (Al-Absi, 2016). Spinelli \& Adam (2012) observed that most of the big businesses available are assumed to have been started as a small business. Microfinance is widely recognized as a crucial tool for poverty alleviation and socio-economic well-being (Sultakeev, Karymshakov, \& Sulaimanova, 2105).

SMEs play a significant role in stabilizing and in the development of emerging economies. Access to financial services is important to their growth and performance. According to Abu, \& Ezike (2012), the experience of many countries indicate that 
entrepreneurship which manifests in the form of SMEs can meaningfully contribute to the attainment of the country's economic development objectives. These objectives include employment generation, income redistribution, output expansion, promotion of indigenous entrepreneurship and technology, location of industries among regions of a country, production of intermediate goods to strengthen, inter and intra industrial linkages. Owners of small businesses source their capital from personal savings, funds from friends and families, cooperative societies, business associates and partners, various financial institutions including Deposit banks and MFBs. Small business finds it difficult to meet the collateral requirements of deposit banks compared to large companies (Babajide, 2012). Microfinance banks are responsible for more than half of the economically active population in Nigeria, who are not banked by the deposit banks since most of them are poor. To deepen the level of financial inclusion, the Central Bank of Nigeria (CBN) seems to be paying more attention to the performance of the MFBs, and their impact on empowering the poor people and MSMEs access to capital (Eigbiremolen, \& Anaduaka, 2014). According to Syed, Muzaffar, \& Mina, (2018), Microfinance activities usually involve: small loans typically for working capital, informal appraisal of borrowers and investments; collateral substitutes, such as group guarantees and compulsory savings, Access to repeat and larger loans, based on repayment performance, and streamlined loan disbursement and monitoring. Microfinance has gained a universal consensus as an effective tool for alleviating poverty and wellbeing improvement (Ebimobowei, Sophia, \& Wisdom, 2012).

\section{Statement of Problem}

Microfinance is the provision of financial services, particularly microcredit, to people who have been systematically excluded from accessing such services by the formal financial institutions (Consultative Group to Assist the poor (CGAP), 2012). There is comparatively little convincing evidence in the grand claims about the success effects of microfinance on small businesses because high cost of over $60 \%$ Annual interest rate on microloans in developing nations means that high returns to capital are needed to improve on tangible outcomes of such business income (Attefah, Mintah, \& Amoako-Agyeman, 2014) while Ngehnevu \& Nembo (2010) carried out a study on a microfinance institution named Camccul, and its customers in Cameroon and concluded that there is a positive impact of microfinance on the development of the SME. SMEs are at a disadvantage compared to big firms in terms of accessing loans from commercial banks. Access to capital is critical to the development of SMEs (Pei-Wen, Zariyawati, Diana-Rose, \& Annuar, 2016).

Owners of small business prefer their savings and cooperative societies credit instead of MFBs and deposit banks loans because of non-accessibility, exorbitant collaterals, and high-interest rates. High interest requested by the microfinance banks has been observed to be the cause of default among the customers (Taiwo, Onasanya, Agwu, \& Benson, 2016).

\section{Research Objective}

The main objective of this research was to ascertain whether there was any 
major effect of microfinance bank products on the financial performance of SMEs in Lagos Metropolis. This study was borne out of conflicting outcomes of previous researches on the topic.

\section{Literature Review}

\subsection{Theoretical Framework \\ 4.1.1 Pecking Order Theory}

Pecking order theory predicts that due to the information asymmetry between a firm and outside investors regarding the real value of both current operations and prospects, external capital (debt and equity) will always be relatively costly compared to internal capital (retained earnings).

Pecking order theory suggests that firms first prefer internal sources of finance (Myers, 1984). When it is necessary to take funds from outside, firms prefer debt to equity because of lower information costs associated with debt issues. Equity is scarcely used (Shyam-sunder \& Myers, 1999). If there are three sources of funding available to firms: retained earnings, debts, and equity. Retained earnings have no adverse selection problem. Equity is subject to serious adverse selection problems, while debt has only a minor adverse selection problem (Frank \& Goyal, 2002). Pecking order theory proposes that cost associated with the funding of institutions will increase with asymmetric information (Myers \& Majluf, 1984; Watson and Wilson, 2002).

\subsection{Definition and History of Microfinance Banking in Nigeria}

According to Ubom (2003), microfinance institution (MFIs) services have evolved to include non-financial services such as micro-insurance, payment services, social intermediation groups, training in financial literacy, and business management. According to Imoisi, \& Godstime, (2014), Microfinance refers to a collection of financial services, including credit, advance, money, and insurance cover, accessible by povertystricken industrialists and small commercial proprietors who have no security and wouldn't otherwise meet the requirements for an average bank loan. According to the Central Bank of Nigeria (2005), Microfinance is about providing financial services to the poor, who mainly constitute the $65 \%$ excluded from access to financial services of conventional banks.

According to Babajide (2011), the practice of microfinance is rooted in Nigerian culture. Long before Central Bank of Nigeria started the issue of microfinance banking, the informal Self-help Groups (SHGs) or Rotating Savings and Credit Association (ROSCAs) have been providing credit to the rural and urban low-income earners including SMEs. These informal groups are present in every part of Nigeria. The Federal government of Nigeria has initiated many programs and organization to reduce the poverty level in the country, to create employment, raise the level of inclusiveness of poor, rural people and micro and small business in financial services, especially banking. These government organizations include Family Economic Advancement Program (FEAP), Peoples Bank of Nigeria (PBN), Nigeria Agricultural Insurance Corporation (NAIC), The Community Banks (CBs), National Directorate of Employment (NDE) and Nigeria Agricultural and Co-operative Bank (NACB) (Imoisi \& Godstime, 2014). In 
2005, the CBN commenced the process of reforms in the community banking sector. The latter resulted in the licensing of microfinance banks (MFBs), to replace community banks, with the goal of making MFBs, to replace community banks, with the goal making MFBs more effective in granting credit to SMEs to develop this sector. Thus, private sector operators were statutorily empowered by the provisions of section 33 subsection (1) (b) of the CBN Act 7 of 2007 to operate MFBs in place of the community banks in Nigeria (CBN, 2008). Presently, there are three categories of microfinance banks (MFBs) in Nigeria, namely Unit MFBs (Tier1 \& 2); State MFBs and National MFBs. A Circular issued to all MFBs by CBN dated March 7, 2019, with reference number FPRD/DIR/GEN/CIR/07/024 titled the 'Review Of Minimum Capital Requirement For Microfinance Banks In Nigeria' the minimum capital requirement for the categories of microfinance banks have been revised as follows:

1. Tier 1Unit Microfinance Bank N200,000,000 (Two Hundred Million Naira)

2. Tier 2 Unit Microfinance Bank N50,000,000 (Fifty Million Naira)

3. State Microfinance Bank N1,000,000,000 (One Billion Naira)

4. National Microfinance Bank N5,000,000,000 (Five Billion Naira)

To aid the process of recapitalization, all microfinance banks are required to comply with the following:

i. Tier 1 Unit Microfinance Banks shall meet a N100million capital threshold by April 2020 and N200 million by April 2021;

ii. Tier 2 Unit Microfinance Banks shall meet a N35 million capital threshold by April 2020 and N50 million by April 2021;

According to CBN Circular FPRD/DIR/GEN/CIR/07/024 there $902 \mathrm{MFBs}$ in Nigeria with about 173 in Lagos State (CBN, 2019).

\subsection{Roles Small Business Play in Developing Countries}

SMEs are defined in terms of their characteristics. These characteristics include the size of capital invested, the number of employees, business turnover, the management style, location, and the market share (Wairimu \& Mwilaria, 2017). In most economies, with a high rate of job growth, it is estimated that SMEs constitute 90percent of total enterprises (World Bank, 2013). SMEs have been accepted as the engine of economic growth and the promoter of equitable development (Christopher, 2007). The activities of SMEs to a reasonable level create employment, which helps the government generate a lot of revenue through taxes used for the developmental project (Haider, Asad, Fatima \& Abidin, 2017). Government generates a lot of revenue through taxes paid by small businesses which are used to undertake development projects in the country (Abor \& Quartey, 2010). The contribution of SMEs to economic development is such that a country can only ignore it to its peril (Oduntan, 2014). According to Oduntan (2014), the following are the roles of SMEs in developing countries, including Nigeria:

(a) Capacity building: SMEs presents an opportunity for training of Entrepreneurs, which leads to wealth creation process at all levels.

(b) Growth promotion: SMEs are involved in primary and secondary economic activities that rest seriously on materials that are sourced locally.

(c) Employment Generation: SMEs in Nigeria are mostly labour intensive. Therefore, SMEs generate employment higher than large enterprises. 
(d) Dispersal of Industries: SMEs could be located easily in rural areas because they only need basic industrial infrastructure. This makes for easy dispersal of industries.

(e) Backward and Forward Linkages: SMEs serves as an industrial linkage between local producers of raw materials and large industrial concerns.

(f) Poverty Alleviation: SMEs play an important role in reducing poverty and inequality among the citizens of a country.

(g) Technological/Industrial Development: The gestation period for SMEs is short, and there is a good opportunity for quick returns on investment.

(h) Acquisition of Technology: SME industries provide opportunities for the development of local skills and technology acquisition through adaptation.

SMEs sector serves as an incubator for new ideas and testing ground for new technologies (Oyetuga et al.; 2008).

According to Oduntan, (2014), the following are the challenges confronting SMEs in Nigeria: Inadequate Access to finance capital, inadequate infrastructural base, inadequate information base, low entrepreneurial skills, and poor policy implementation. According to Nwachukwu \& Ogbo (2012), Microenterprises in Nigeria have not made the desired impact on Nigeria's economy.

\subsection{Microfinance Bank Products for Small Businesses}

Generally, Microfinance is known as a provision of a wide range of financial services such as credit, insurance, savings, deposit, and payment services to poor and low-income households who are excluded from conventional financial services for lack of collateral together with non financial services (Al-Shami, Majid, Abdul Rashid \& Abdul Hamid, 2014; Gyimah \& Boachie , 2018).

\section{Microfinance Product/Service}

Microloan: Microloan is an important aspect of microfinance, and it has been described as the premise of microfinance institutions (Alhassan, Hoedofia \& Braima, 2016). These are funds that are given to small enterprises or individuals business owners over a period of time. The terms microloan and microcredit are used by SMEs to increase their working capital, which leads to an increase in turnover and growth in terms of profit, and size of the firm.

Micro-savings: Long before the advent of MFIs, individuals and small businesses have been engaged in daily, weekly, and monthly contributions referred to as "Esusu." Even many MFBs in Nigeria are still engaged in this micro savings, whereby the officers of the MFBs go out to collect contributions daily, weekly, and monthly from individuals and small businesses. Often banking products are developed for these micro savings. MFBs take care of the Micro savings needs of the small businesses in the informal markets and rural areas to help them save, invest, and grow their businesses (Gyimah \& Boachie, 2018).

Micro Insurance: This is the insurance of the activities of the customers of microfinance banks (Oscar \& Abor, 2013). Mathur (2012) defines microinsurance as a low-value product that requires different design and distribution schemes low premium that is based on community risk rate. Microfinance insurance involves life, health, property, and other valuable items of business (Gyimah \& Boachie, 2018).

Education: MFBs provide educational training to SMEs through efficient utilization of 
resources, inventory management, and record keeping. MFBs also trains their customers in many areas; accounting, marketing, writing of business plans, cooperation among customers of the same trade, the formation of cooperative societies. These are nonfinancial services provided by MFBs (Gyimah \& Boachie, 2018). During educational training and workshops, MFBs recommend solutions to the challenges of business owners that could eventually help their businesses to grow (Sorpong-Danquah, Gyimah, Poku \& Osei-poku, 2018).

\subsection{Challenges of Microfinance Banks in Nigeria}

According to Abu \& Ezike (2012), the following are the challenges facing microfinance Banks:

- High operating cost: Loan monitoring and collection requires many staff, loan application review, management of several locations,

- Repayment problem: A lot of SMEs default in loan repayment, which affects the operation of the banks.

- Inadequately experienced credit staff: Microfinance dispenses lots of loans. Therefore MFBs need experienced credit staff for appraisal and recommendation of viable loans for disbursement.

- Problems of illiteracy: Borrowers (SMEs) find it difficult to keep proper accounting records that will enable MFBs to take decisions on their loans. Inability to monitor loan of SMEs adequately leads to loan defaults.

According to Ekpete \& Iwedi (2017), Weak Capital Base is a problem associated with MFBs, which has led to the erosion of shareholders funds through losses. Other fundamental problems of MFBs include inadequate technical know-how in managing MFBs, poor culture of corporate governance practices, management information system challenges, high operating costs, inadequate loanable funds and lack of awareness of microfinance services.

According to Nwanyawu, (2011), MFBs face the following problems in Nigeria: Diversion of microfinance fund, inadequate finance, frequent changes/contradiction in government policies, high loan defaults, low capacity and low technical skills by operators of MFBs.

Other challenges of MFBs include: Ineffective credit bureau that encourages loan defaulters to move from one MFB to another, few individuals and firms want to put their savings and deposit in MFBs because they are not considered safe, inadequate banking software to support operations, low salaries paid by MFBs make them unattractive to skilled personnel, lack of proper risk management and internal control units to support banking operations, and inconsistent government policies.

\subsection{Empirical Reviews}

Taiwo, Yewande, Edwin, \& Benson (2016) analyzed the role of microfinance institutions in financing small businesses. They used primary data obtained in an interview in 15 small businesses across Lagos state. Their finding revealed that microfinancing significantly promoted businesses by reducing the resource gap for small businesses. Quaye (2011) made a study on selected SMEs in the Kumasi metropolis. The 
research findings revealed that the MFIs had helped SMEs by providing greater access to credit in comparison to traditional banks. Also, SMEs were found to deal with more than one MFI. The credit has helped to boost their capital and expand their businesses. The research mentioned challenges: the inability of clients (customers) to repay the loans, the misappropriate rate of credit, and the request of collateral security, which negatively affect SME as some cannot provide them. The research indicated that MFIs have a positive effect on the growth of SMEs. The results of a research carried out by Obokoh, Monday \& Ojiako (2016) on microfinance banks and SME: the Nigerian experience revealed that there is a positive contribution of microfinance lending to the development of SMEs. Babajide (2012) investigated the effects of microfinance on the growth of SMEs in Nigeria. The research used multiple regression analysis. It measured the 502 randomly selected financial enterprises by MFBs. The study revealed that access to microfinance did not enhance the growth of small business in Nigeria. Microfinance lending in Nigeria has not been positive, as shown in the formal model approach examined by Arogundade, (2010).

Some literature has shown that microfinance has a positive impact on SMEs through participation in microcredit schemes because of less stringent loan conditions, which makes SME make optimal use of resources, thereby increase revenue, profit and employment generation (Field et. al; 2013; Wang, 2013; Buera et al.; 2012). Okafor, Ezeaku \& Ugwuegbe (2016) examined the impact of microcredit on poverty reduction in Nigeria for the periods 1999 to 2014. The results showed that microfinance has a negative and nonsignificant effect on poverty reduction in Nigeria. Based on the findings, they concluded that microcredit had not played any vital role in alleviating poverty in Nigeria. A study conducted by Adebusuyi, Sere-Ejembi, Nwolisa and Ugoji (2008) stated that financial services provided to the economically active poor by MFBs drive economic activities and employment generation by contributing to the commencement or expansion of income generating ventures. Nwakwo, Olukotu, and Abah (2013) asserted in a research carried out on the impact of Microfinance on rural transformation in Nigeria that microfinance banks have difficulties in loan repayment, illiteracy among the poor and inadequate monitoring of loans of SMEs by MFBs. Empirical evidence from the study carried out by (Apere, 2016) in Nigeria shows that the activities of MFBs can influence the entire economy if it is well coordinated. Also, the results of the study indicate that $\mathrm{MFB}$ loans and domestic investment significantly and positively affect the growth of Nigeria's economy. Onwuka, Udeh \& Nwannebuike, (2015) investigated the impact of rural credit facilities of MFBs on poverty alleviation in Nigeria for the periods 2005 to 2012 in Anambra, Enugu, and Imo states of Nigeria. The study showed that deposits mobilized from rural communities by MFBs were siphoned out of the communities by way of fixed deposits with commercial banks usually located outside the communities thereby defeating the sole idea of financial intermediation within the communities.

\section{Research Method}

The population for this study consists of SME owners within Lagos metropolis. A purposeful sample was used to select respondents. The measuring instruments used 
for the study was adapted from a study carried out by Kaliu \& Omwansa (2015) titled Effects of Microfinance Institutions' Products on Financial Performance of SMEs: A Case Study of Machakos Town, Kenya. The questionnaire administered contained two parts: Part 1: contains general information while Part 2: effects of micro savings, and training on the performance of SMEs. All items in Section B were arranged on a fivepoint Likert Scale of Strongly Agree, Agree, Neutral, Disagree, and Strongly Disagree respectively. SPSS package was used to analyze the data.

\section{Results}

Questionnaires designed to determine the impact of Micro Finance Banks (MFBs) on the growth of SMEs were distributed in Lagos metropolis. Two hundred and nine questionnaires were distributed; however, 205 viable questionnaires were analyzed. The questionnaire was formulated using a Likert scale ranging from Strongly Agree (5) to Strongly Disagree (1).

Table 1: Characteristics of Entrepreneurs

\begin{tabular}{lcc}
\hline Characteristic & Frequency & Percentage \\
\hline INDUSTRY & 122 & \\
Trading & 5 & $60 \%$ \\
Consulting & 3 & $2 \%$ \\
Photography & 4 & $1 \%$ \\
Information Technology & 18 & $2 \%$ \\
Engineering & 4 & $9 \%$ \\
Health & 3 & $2 \%$ \\
Food \&Beverage & 14 & $1 \%$ \\
Fashion & 2 & $7 \%$ \\
Publishing & 12 & $1 \%$ \\
Education & 4 & $6 \%$ \\
Real Estate & 7 & $2 \%$ \\
Finance & 7 & $3 \%$ \\
Others & & $3 \%$ \\
\hline Number of Employees & 154 & \\
$1-5$ & 33 & $75 \%$ \\
6-10 & 18 & $16 \%$ \\
$>10$ & & $9 \%$ \\
\hline Legal Status & 175 & \\
Enterprise & 30 & $85 \%$ \\
Limited & & $15 \%$ \\
\hline Date of Commencement & 9 & \\
Before 2000 & 16 & $4 \%$ \\
2000 - 2005 & 48 & $8 \%$ \\
2006 - 2010 & 97 & $23 \%$ \\
2011 - 2015 & 35 & $47 \%$ \\
2016 till date & 205 & $17 \%$ \\
\hline Total & & $100 \%$ \\
\hline
\end{tabular}


The table above shows the characteristics of the SME businesses interviewed in Lagos. Data were collected from 205 MFB customers. The businesses were seen to operate in various sectors of the economy with Trading taking the lead at $60 \%$, followed by the Engineering industry (9\%), Fashion industry (7\%), Education (6\%), Finance (3\%), Consulting (2\%), Health $(2 \%)$, Information Technology $(2 \%)$, Real estate $(2 \%)$ Food \& Beverages (1\%), Photography (1\%) and Publishing (1\%). Majority of the entrepreneurs $(75 \%)$ had one to five employees, $16 \%$ had six to ten employees, while $9 \%$ had more than ten employees. The businesses were majorly (85\%) registered business names, while $15 \%$ were limited liability companies. When asked the year they commenced their businesses, the majority (47\%) said they started between years 2011 and 2015, 23\% started within the years 2006 to 2010, 17\% started within the years 2016 to 2019, 8\% within the years 2000 and 2005 and 4\% before the year 2005.

Table 2: Statements on Effects of Micro Savings on Financial Performance

\begin{tabular}{|c|c|c|c|}
\hline $\mathrm{S} / \mathrm{N}$ & VARIABLE & MEAN & \begin{tabular}{|c|} 
STD \\
DEVIATION
\end{tabular} \\
\hline 1 & $\begin{array}{l}\text { The minimum savings allowed by MFBs affect the financial } \\
\text { performance of the business }\end{array}$ & 4.07 & 0.80 \\
\hline 2 & $\begin{array}{l}\text { The interest rate on savings offered by the MFBs affect the } \\
\text { financial performance of the business }\end{array}$ & 4.11 & 0.80 \\
\hline 3 & $\begin{array}{l}\text { The various types of savings accounts offered by the MFBs } \\
\text { affect the financial performance of the business }\end{array}$ & 3.94 & 0.84 \\
\hline 4 & $\begin{array}{l}\text { Savings through mobile banking allowed by the MFBs affect } \\
\text { the financial performance of the business }\end{array}$ & 3.98 & 0.85 \\
\hline 5 & $\begin{array}{l}\text { Micro-savings service offered by the MFBs is important in the } \\
\text { financial performance of the business }\end{array}$ & 3.95 & 0.87 \\
\hline
\end{tabular}

The respondents were asked to rank their level of agreement to statements on the effects of micro-savings on financial performance. Results from analysis of their responses showed positive means ranging from 3.94 to 4.11 with a standard deviation between 0.80 and 0.87 . The statement "The interest rate on savings offered by the MFBs affect the financial performance of the business" had the highest mean (4.11) followed by "The minimum savings allowed by MFBs affect the financial performance of the business" (4.07). The statement "The various types of savings accounts offered by the MFBs affect the financial performance of the business" had the least mean (3.94).

Table 3: Effects of Micro Credit on Financial Performance of SMEs

\begin{tabular}{|c|c|c|c|}
\hline $\mathbf{S} / \mathbf{N}$ & VARIABLE & MEAN & \begin{tabular}{|c|} 
STD \\
DEVIATION
\end{tabular} \\
\hline 1 & $\begin{array}{l}\text { The duration to receive loans from the MFBs affect the } \\
\text { financial performance of the business }\end{array}$ & 4.15 & 0.71 \\
\hline 2 & $\begin{array}{l}\text { Long term loans offered by the MFBs affect the financial } \\
\text { performance of the business }\end{array}$ & 4.11 & 0.76 \\
\hline 3 & $\begin{array}{l}\text { Medium term loans provided by the MFBs affect the } \\
\text { financial performance of the business }\end{array}$ & 4.12 & 0.68 \\
\hline 4 & $\begin{array}{l}\text { Short term loans provided by the MFBs affect the financial } \\
\text { performance of the business }\end{array}$ & 3.54 & 1.09 \\
\hline
\end{tabular}




\begin{tabular}{|c|c|c|c|}
\hline $\mathbf{S} / \mathbf{N}$ & VARIABLE & MEAN & $\begin{array}{c}\text { STD } \\
\text { DEVIATION }\end{array}$ \\
\hline 5 & $\begin{array}{l}\text { The security required for loans by the MFBs affects the } \\
\text { financial performance of the business }\end{array}$ & 3.95 & 0.88 \\
\hline 6 & $\begin{array}{l}\text { The rate of interest on loans offered by the MFBs affects } \\
\text { the financial performance of the business }\end{array}$ & 4.10 & 0.78 \\
\hline 7 & $\begin{array}{l}\text { The mode of disbursement of loans from the MFBs affect } \\
\text { the financial performance of the business }\end{array}$ & 4.02 & 0.79 \\
\hline 8 & $\begin{array}{l}\text { The repayment period of loans offered by he MFBs affect } \\
\text { the financial performance of the business }\end{array}$ & 4.01 & 0.85 \\
\hline 9 & $\begin{array}{l}\text { The maximum lending limit provided by the MFBs affect } \\
\text { the financial performance of the business }\end{array}$ & 4.04 & 0.79 \\
\hline
\end{tabular}

The respondents were asked to rank their level of agreement to statements on the effects of microcredit on financial performance. Results from analysis of their responses showed positive means ranging from 3.54 to 4.15 with a standard deviation between 0.68 and 1.09. The statement "The duration to receive loans from the MFBs affect the financial performance of the business" had the highest mean (4.15) followed by "Medium-term loans offered by the MFBs affect the financial performance of the business" (4.12). The statement "Short term loans offered by the MFBs affect the financial performance of the business" had the least mean (3.54).

Table 4: Effects of Training on Financial Performance of SMEs

\begin{tabular}{|c|c|c|c|}
\hline $\mathrm{S} / \mathbf{N}$ & VARIABLE & MEAN & $\begin{array}{c}\text { STD } \\
\text { DEVIATION }\end{array}$ \\
\hline 1 & $\begin{array}{l}\text { The frequency of training offered by the MFBs affect the } \\
\text { financial performance of the business }\end{array}$ & 3.60 & 1.09 \\
\hline 2 & $\begin{array}{l}\text { Training on management skills by the MFBs affect the } \\
\text { financial performance of the business }\end{array}$ & 3.79 & 1.00 \\
\hline 3 & $\begin{array}{l}\text { Training on record keeping by the MFBs affects the financial } \\
\text { performance of the business }\end{array}$ & 3.28 & 1.23 \\
\hline 4 & $\begin{array}{l}\text { Training on the proper use of the loans by the MFBs affects } \\
\text { the financial performance of the business }\end{array}$ & 3.30 & 1.33 \\
\hline 5 & $\begin{array}{l}\text { Training on the investment areas by the MFBs affects the } \\
\text { financial performance of the business }\end{array}$ & 3.23 & 1.21 \\
\hline
\end{tabular}

The respondents were asked to rank their level of agreement to statements on the effects of training on financial performance. Results from analysis of their responses showed positive means ranging from 3.23 to 3.79 with a standard deviation between 1.00 and 1.33. The statement "Training on management skills by the MFBs affect the financial performance of the business" had the highest mean (3.79) followed by "The frequency of training offered by the MFBs affect the financial performance of the business" (3.60). The statement "Training on the investment areas by the MFBs affects the financial performance of the business" had the least mean (3.23). 
Table 5: Financial Performance

\begin{tabular}{|c|c|c|c|}
\hline $\mathbf{S} / \mathbf{N}$ & VARIABLE & MEAN & \begin{tabular}{|c|} 
STD \\
DEVIATION
\end{tabular} \\
\hline 1 & $\begin{array}{l}\text { The amount of business capital was more in } 2018 \text { than in } \\
2017 \text { as a result of using MFBs' products. }\end{array}$ & 3.90 & 0.89 \\
\hline 2 & $\begin{array}{l}\text { The amount realized by the business for net profits in } 2018 \\
\text { was more than in } 2017 \text { as a result of using MFBs' products }\end{array}$ & 3.90 & 0.87 \\
\hline 3 & $\begin{array}{l}\text { The use of microfinance products is the only way to improve } \\
\text { the financial performance of the business }\end{array}$ & 2.52 & 1.00 \\
\hline
\end{tabular}

The respondents were asked to rank their level of agreement to statements on the impact of MFBs' products on their financial performance. Results from analysis of their responses showed means ranging from 2.52 to 3.90 with a standard deviation between 0.87 and 1.00. The statements "The amount of business capital was more in 2018 than 2017 as a result of using MFBs' products" and "The amount realized by the business for net profits in 2018 was more than 2017 as a result of using MFBs' products" had the highest means (3.90). The statement "The use of microfinance products is the only way to improve the financial performance of the business" had the least mean (2.52).

\section{Discussion \& Conclusion}

Majority of the respondents were in the trade industry, although the population was well represented across other sectors of the economy. The population was also majorly enterprise with only $15 \%$ as limited companies. The business owners are also perceived to be experienced in entrepreneurship based on their years of business commencement.

The interest rate of MFBs savings has always been a major selling point as it is higher than offers from commercial banks; this encourages savings amongst business owners, and this, in turn, impacts financial performance positively. The minimum savings also helps to safeguard a percentage of the SME owners' funds from avoidable expenses. The duration for which they disburse loans is even faster than that of commercial banks. Although, majority of the SMEs had not experienced training by an MFB; the "means" for SMEs who had experienced MFB training showed the importance of management skills training for SME owners. The study also reveals that the majority of the SMEs experienced financial growth using MFBs' products, thus showing that MFBs impact them positively. However, responses also revealed that the SMEs do not perceive MFB products as the only way for the financial performance of SMEs.

In conclusion, the study portrays that MFBs largely impact SMEs in Lagos. It is therefore important that all MFBs adopt training techniques to educate their customers accordingly as the study showed a poor prevalence of MFB training amongst the respondents.

\section{Reference}

Abor, J., \& Quartey, P. (2010). Issues in SME development in Ghana and South Africa. International Research Journal of Finance and Economics, 39(6), 215-228. Retrieved from www.eurojournals.com 
Abu, N. I. \& Ezike, E. J. (2012). The role and sustainability of microfinance banks in reducing poverty. International Journal of Business Administration, 3(3), doi:10.5430/ijba.v3n3p33

Adama, U. J., Duru, U. I. \& Diyoke, O. K. (2017). The role of microfinance banks on employment generation in the grassroots: Evidence from Karu Local Government Area of Nasarawa State, Nigeria. Asian Journal of Economics, Business, and Accounting, 4(2): 1-9, doi: 10.9734/AJEBA/2017/35325

Adebusuyi B., Sere-Ejembi A., Nwolisa C, \& Ugoji C.(2008). Towards a sustainable microfinance development in Nigeria. Abuja, Nigeria: Research Department, Central Bank of Nigeria, Abuja. Retrieved from Retrieved from www.cenbank.org

Al-Absi, A. A. (2016). Impact of microcredit in microfinance banks on small business spread in Yemen (Case study of Sana'a, Yemen). International Journal of Business and Management Invention, 5(11), 14-29. Retrieved from www.ijbmi.org

Alhassan, E. A., Hoedoafia, M. A., \& Braimah, I. (2016). The Effects of Microcredit on Profitability and the Challenges on Women Owned SMEs: Evidence from Northern Ghana. Journal of Entrepreneurship and Business Innovation, 3(1), 29-47. doi:10.5296/jebi.v3i1.9244

Al-Shami, S.S.A., Majid, I, B., Abdul Rashid, N. \& Abdul Hamid, M.S.R. (2014). Conceptual Framework: The Role of Microfinance on the Wellbeing of Poor People Cases Studies from Malaysia and Yemen. Asian Social Science, 10, 230-242. doi: doi:10.5539/ass.v10n1p230

Apere, T. O. (2016). The Impact of Microfinance Banks on Economic Growth in Nigeria. International Journal of Academic Research in Economics and Management Science, 5(4), 5361.doi:10.6007/IJAREMS/v5-i4/2290

Arogundade K. K. (2010) Effective microfinance and SME: The true story. Journal of Management and Society 1(2), 51-54. Retrieved from scholar.google.com

Attefah, K. J., Mintah, E. K. \& Amoako-Agyeman, F. K. (2014) The effect of microfinance institutions on the growth of small businesses in Kumasi, Ashanti region of Ghana. International Journal of Economics, Commerce and Management, 2(6), 1-39. Retrieved from www. ijecm.co.uk/

Babajide, A. (2011). Impact analysis of microfinance in Nigeria. International Journal of Economics and Finance, 3(4), 217,225. doi:10.5539/ijef.v3n4p217

Babajide, A. (2012). Effects of microfinance on micro and small enterprises (MSEs) growth in Nigeria. Asian Economic and Financial Review, 2(3), 463-477. Retrieved from www.ideas.repec.org

Buera, F. J., Kaboski, J. P. \& Shin, Y. (2012). The Macroeconomics of Microfinance. RB of St. Louis Working Paper, 2013-034A, doi:10.3386/w17905

Central Bank of Nigeria. (2008). Annual Report and Statement of Accounts. Central Bank of Nigeria. Retrieved from www.cenbank.org

Central Bank of Nigeria. (2008). Guidelines and Procedures for the establishment of Microfinance Banks in Nigeria Published by the CBN. Retrieved from www.cenbank.org

Central Bank of Nigeria (2005). Microfinance, Regulatory \& Supervisory framework for Nigeria. Retrieved from www.cenbank.org

Chetama, J. C., Dzanja, Dzanja, J, Gondwe, Gondwe, S. \& Maliro, D. (2016). The Role of Microfinance on Growth of Small-Scale Agribusinesses in Malawi: A Case of Lilongwe District. Journal of Agricultural Science, 8(6), 84-93.doi: doi:10.5539/jas.v8n6p84

Christopher, I.F., 2007. Impact of microfinance on small and medium-sized enterprises in Nigeria. Proceedings of the 7th International Conference on Innovation \& Management, 1864 -1871 Retrieved from pdfs.semanticscholar.org

Ebimobowei, A., Sophia, J. M., \& Wisdom, S. (2012). An Analysis of Microfinance and Poverty Reduction in the Bayelsa State of Nigeria. Arabian Journal of Business and Management Review, 1(7), 38-57. Retrieved from www.ccsenet.org

Eigbiremolen, G.O. \& Anaduaka, U. S. (2014) (The Place of Microfinance in Today's Economy: Further Evidence from Nigeria. International Journal of Academic Research in Economics and Management Science, 3, 12-21. doi: 10.6007/IJAREMS/v3-i1/551

Ekpete, M.S. \& Iwedi, M. (2017). Financial intermediation functions of microfinance banks in Nigeria: A vector autoregressive and multivariate approach. International Journal of Economics and Financial Modelling,2, 7-24. doi:10.20448/811.2.1.7.24

Field, E., Pande, R., Papp, J. \& Rigol, N. (2013). Does the classic microfinance model discourage entrepreneurship among the poor? Experimental evidence from India. American Economic Review, 103(6), 2196-2226, doi:10.1257/aer.103.6.2196 
Frank, M. Z. \& Goyal, V. G. (2002). Testing the pecking order theory of capital structure. Journal of Financial Economics, 67(2), 217-248.doi: 10.1016/S0304-405X(02)00252-0

Gyimah, P \& Boachie, W. K. (2018). Effect of Microfinance Products on Small Business Growth: Emerging Economy Perspective. Journal of Entrepreneurship and Business Innovation, 5. 59-71. doi:10.5296/jebi.v5i1.12378

Haider, S. H., Asad, M., Fatima, M., \& Abidin, R. Z. U. (2017). Microfinance and Performance of Micro and Small Enterprises: Does Training have an Impact. Journal of Entrepreneurship and Business Innovation, 4(1), 1-13.doi: 10.5296/jebi.v4i1.10566

Imoisi, A. I. \& Godstime, I, O. (2014). Microfinance and its impact on poverty alleviation: A case study of some microfinance banks in Edo State, Nigeria. American Journal of Humanities and Social Sciences, 2, 27-41. doi: 10.11634/232907811402456

Kalui, F. M. \& Omwansa, D. M. (2015). Effects of Microfinance Institutions' Products on Financial Performance of Small and Medium Enterprises; A Case of Machakos Town, Kenya. Journal of Business and Management, 7(14), 50-57. doi: 10.9790/487X-17455057

Karlan, D., \& Zinman, J. (2010). Expanding credit access: Using randomized supply decisions to estimate the impacts. Review of Financial Studies, 23, 433-464. Retrieved from www.deankarlan.com

Mathur, S. (2012). Micro Insurance-A Powerful Tool to Empower Poor. Management Insight, 6(2), 89-91. Retrieved from www.citeseerx.ist.psu.edu

Myers, S.C. (1984). The capital structure puzzle. Journal of Finance 39(3), 575-592. Retrieve from www.jstor.org

Myers, S.C. \& Majluf, N. (1984). Corporate financing and investment decisions when firms have information that investors do not have. Journal of Financial Economics 13(2) 187-221.

doi: doi:10.1016/0304-405X(84)90023-0

Ngehnevu, C. B. and Nembo, F. Z. (2010). The Impact of Micro Finance Institutions (MFIs) in the Development of Small and Medium Size Businesses (SMEs) in Cameroon. (Published BSc Thesis). University of Agricultural Sciences, Uppsala, Swedish.

Nwachukwu, A. \& Ogbo, A. (2012). The role of entrepreneurship in economic development: The Nigerian perspective. European Journal of Business Management, 4(8), 96-110. Retrieved from www.iiste.org

Nwankwo, O., Olukotu, G. A., \& Abah, E. (2013). Impact of Microfinance on Rural Transformation in Nigeria. International Journal of Business and Management. 8(190),99-106. doi: doi:10.5539/ijbm.v8n19p99

Nwanyawu OJ (2011) Microfinance in Nigeria: Problems and Prospects. African Research Review 5, 87-103. doi: 10.4314/afrrev.v5i2.67307

Obokoh, L. O., Monday, J. M. \& Ojiako, U. (2016). Microfinance banks and small and medium sized enterprises access to finance: the Nigerian experience. Banks and Bank Systems, 11(4), 111-121. doi: 10.21511/bbs.11(4-1).2016.01

Oduntan, K. O. (2014). The Role of small and medium enterprises in economic development: The Nigerian experience. International Conference on Arts, Economics and Management, 22-23, doi:10.15242/ICEHM.ED0314038

Okafor I.G., Ezeaku H.C, \& Ugwuegbe S. (2016). Microcredit and poverty reduction: A case of Nigeria. International Journal of Multidisciplinary Research and Information. 2(4):319-325.

Onwuka I. O, \& Udeh, N. S. (20150. Impact of rural credit facilities of Microfinance Banks on poverty alleviation: The Nigerian Experience. European Scientific Journal.11(28):481-512. Retrieved from www.eujournal.org

Oscar, A.J. \& Abor, J. (2013). Risk management in the Ghanaian insurance industry. Qualitative Research in Financial Markets, 5(1), 26-42. doi:10.1108/17554171311308940

Quaye, D. N. O. (2011). The Effect of Microfinance Institutions on the Growth of Small and Medium Scale Enterprises (SMEs): A Case Study of Selected SMEs in Kumasi Metropolis [Master Thesis]. Kwame Nkrumah University of Science and Technology, Institute of Distance Learning, Ghana.

Pei-Wen, T., Zariyawati, M.A, Diana-Rose, F. \& Annuar, M.N. (2016). Impact of Microfinance facilities on performance of small, medium enterprises in Malaysia. World Applied Sciences Journal, 34 (12): 18451849. doi: 10.5829/idosi.wasj.2016.1845.1849

Sanya, O. \& Polly, M. (2017). The impact of microfinance on microenterprises. Investment Management and Financial Innovations, 14(3), 82-92. doi:10.21511/imfi.14(3).2017.08 
Sarpong-Danquah, B., Gyimah, P., Poku, K., \& Osei-Poku, B. (2018). Financial literacy assessment on tertiary students in Sub-Saharan Africa: A Ghanaian perspective. International Journal of Accounting and Financial Reporting, 8(2), 76-91. doi:10.5296/ijafr.v8i2.12928

Shyam-Sunder, L., Myers, S.C. (1999). Testing static tradeoff against pecking order models of capital structure. Journal of Financial Economics 51, 219-244. doi: 10.1016/S0304-405X(98)00051-8

Spinelli, S. \& Adams, R. (2012). New venture creation: Entrepreneurship for the 1st century, the global entrepreneurial revolution for a flatter world (9th ed.). USA, New York, McGraw-Hill Education, 5-21. Retrieved from searchworks.stanford.edu

Sultakeev, K., Karymshakov, K. \& Sulaimanova, B. (2105). The impact of microfinance on entrepreneurship in Kyrgyzstan. Acta Oeconomica Pragensia, 2018, 26(2), 24-40. doi:0.18267/j.aop.599

Syed, H.H., Muzaffar, A. \& Mina, F. (2018). Microfinance and performance of micro and small enterprises; Does training has an impact. International Journal of Small Business and Entrepreneurship Research, 6(4), 40-49. Retrieved from UK www.eajournals.org

Taiwo J. N., Onasanya, A. Y., Agwu, M.E. \& Benson, K.N. (2016). The role of microfinance institutions in financing small businesses. Journal of Internet Banking and Commerce, 21, 2-20. Retrieved mww. icommercecentral.com

Ubom, E. (2003). Entrepreneurship, Small and Medium Enterprises, Theory, Practices, and Policies. Lagos: Sediman Limited.

Wairimu, Z. Mwilaria, S.M (2017). Microfinance institutions' social intermediation and micro and small enterprises survival in Thika Town, Kenya. (2017). Asia Pacific Journal of Multidisciplinary Research, 5(2), 87-93. Retrieved from www.apjimr.com

Wang, X. (2013). The Impact of Microfinance on the Development of Small and Medium Enterprises: The Case of Tairhou, China. Baltimore, MD: The Johns Hopkins University.

Watson, R. \& Wilson, N. (2002). Small and medium size enterprise financing: A note on some of the empirical implications of a pecking order. Journal of Business Finance and Accounting, 29 (3- 4), 557 578. doi:10.1111/1468-5957.00443

World Bank. (2013). Attacking poverty: World development report 2012/2013. New York: Oxford University Press. 